\section{Health care users' satisfaction in Brazil, 2003}

\author{
Satisfação dos usuários com a assistência \\ de saúde no Brasil, 2003
}

\author{
${ }^{1}$ Centro de Pesquisa Aggeu \\ Magalhães, Fundação \\ Oswaldo Cruz, Recife, Brasil. \\ 2 Centro de Informação \\ Científica e Tecnológica, \\ Fundação Oswaldo Cruz, \\ Rio de Janeiro, Brasil. \\ Correspondence \\ G. C. Gouveia \\ Departamento de Saúde \\ Coletiva, Centro de Pesquisa \\ Aggeu Magalhães, \\ Fundação Oswaldo Cruz. \\ $A \nu$. Moraes Rego s/n, \\ Recife, $P E$ \\ 50670-420, Brasil. \\ giselle@cpqam.fiocruz.br
}

\section{Abstract}

Evaluation of users' satisfaction with the health system brings back longstanding questions concerning the quality of services provided to the Brazilian population. The current study analyzes satisfaction with outpatient and inpatient care based on the results of the World Health Survey, conducted in Brazil in 2003. To explain satisfaction with various aspects of care through a small number of factors, the factor analysis technique was used, through principal components analysis (PCA). Multiple regression models identified associations between satisfaction scores and different sociodemographic variables. For outpatient care, waiting time showed the lowest degree of satisfaction, and in the case of hospitalization, freedom to choose the physician was the worst evaluated aspect. Three components were extracted from the PCA, related respectively to satisfaction with health professionals, health services, and health problem solution. Multiple regression analysis showed that having experienced some type of discrimination (on the basis of gender, age, poverty, social class, skin color, or type of disease) and being an exclusive user of the public National Health System involved a lower degree of users' satisfaction.

Consumer Satisfaction; Discrimination in the Health Sector; Health System
Giselle Campozana Gouveia ${ }^{1}$ Wayner Vieira de Souza 1

Carlos F. Luna 1

Paulo Roberto Borges de Souza-Júnior 2 Célia Landmann Szwarcwald 2

\section{Introduction}

The history of medicine is marked by the relationship between health services and users as an indicator of health care changes occurring over time. While technological advances have proven significant for solving health problems, the disease-centered biomedical model has displayed decreasing interest in patients themselves and their subjectivity. No improvement in health practices has been observed on the basis of fundamental attitudes involving humanitarian and ethical values 1 .

The Brazilian health system shifted from an approach based on public health campaigns (from the late 18th century until 1965) to a private medical care model until reaching the prevailing model in the 1980s, with the Sistema Único de Saúde - SUS (Unified National Health System) 2,3 . The $8^{\text {th }}$ National Health Conference in 1986 consolidated the political and ideological proposals of the so-called Health Reform Project 4,5, highlighting three fundamental aspects: the expanded health concept, whereby health is the combined result of conditions in nutrition, housing, education, income, leisure, transportation, employment, freedom, the environment, access to and possession of land, and access to health services; health as a citizen's right and the duty of the state; and creation of SUS, with universality, integral care, and decentralization as the essential principles 5,6. 
With the implementation of the unified health system and its expanded universalization, there was a reduction in the quality of public services, resulting from an increased demand without the corresponding health care network and necessary infrastructure to meet it. The health sector failed to generate the mechanisms to ensure sufficient support and resources for autonomous services management 7 .

Given this new situation as well as the incorporation of recent technological advances by the health field, it is necessary to conduct periodic evaluations of health services, specially from the user's satisfaction perspective, as a fundamental initiative in the improvement of services organization and professional practices 8,9,10.

In general, and particularly in the Brazilian case, the health status of the population depends not only on overall living conditions, but also on equitable access to services provided with satisfactory quantity and quality 11,12 .

According to Donabedian 13, the classification of quality assurance methods includes structures, processes, and results. In the results approach, patient's satisfaction should be considered an expected result, extending beyond cure, restoration of functional capacity, and reduction of suffering 14 .

Recent data indicate that some $25.0 \%$ of the Brazilian population is covered by private health plans, while the vast majority of the remaining $75.0 \%$ use SUS or pay directly out of pocket for services 15 .

A population-based survey was held in Brazil in 2003, the World Health Survey (WHS) - as part of a World Health Organization (WHO) project focused on health system performance assessment in member countries. Among the surveyed aspects was the evaluation of health care provision, based on the concept of "responsiveness" 16 , aimed at establishing parameters to evaluate health care from the perspective of users' expectations.

Using the data from the Brazilian WHS, the current study aims to evaluate the degree of user's satisfaction with provided health care (both outpatient and inpatient), establishing differences by sociodemographic characteristics and comparing the degree of satisfaction of individuals who used public services with those who paid out of pocket or used private health plans.

\section{Methodology}

The sampling was conducted in three selection stages. In the first stage, 250 census tracts were selected, with probability proportional to size. Tract situation (urban or rural) and municipality size $(<50,000 ; 50,000-399,999$; and 400,000 or more inhabitants) explicitly stratified the primary selection units. The census tract socioeconomic level, defined according to the mean income of the tracts household heads, was used for implicit stratification.

In each tract, households were selected with equiprobability using an inverse sample design to assure 20 households interviewed by sector. In the third stage, only one individual (selected with equiprobability among the household residents) was selected for the interview.

The questionnaire was modular, and the current analysis used the health system responsiveness module. The present study included: (1) all individuals who had been hospitalized in the previous five years (stayed overnight in a hospital or other type of long-term care facility (2) among all those who had not been hospitalized in the previous five years, all the individuals who had used some health service in the previous year (outpatient care).

The first stage of this work included a descriptive analysis of the degree of satisfaction based on a set of variables that expressed the user's degree of satisfaction, according to five response levels ( $1=$ very good to $5=$ very bad $)$, covering the following aspects: traveling time to the health care provider; waiting time before being attended to; being greeted and talked to respectfully; respect for intimacy during physical examination and care; clarity of explanations by the health care providers; availability of time to ask questions about the health problem or treatment; possibility of obtaining information on other types of treatment or tests; participation in decision-making on the health care or treatment; patient's freedom to speak privately with the health professionals; personal information kept confidential; freedom to choose the physician; inside the facility cleanliness including toilets; and available space in waiting and examination rooms.

Among individuals who received inpatient care, two additional aspects were included: ease in receiving visits by family members contact with the outside world.

For each of the items, the degree of satisfaction was estimated by the percentage of "good" or "very good" answers and the percentage of positive answers to three other dichotomous variables (yes or no), related to the health pro- 
fessional's skills, availability of medicines, and adequacy of equipment in the care. Percentages of satisfaction were analyzed by "type of care" - outpatient or inpatient, and by "form of payment" - none (SUS); out-of-pocket or health plan (non-SUS).

Individuals were also asked whether they felt they had been treated worse by the health care providers (whether they felt discriminated) for on any of the following reashes: sex, age, lack of money, social class, ethnic group or skin color, type of illness, or nationality.

To explain total variation in the data set using a small number of factors, the second stage of the analysis used the factor analysis technique with principal components extraction 17 . After a rotation procedure to obtain a simple structure in the factor loading matrix, the factors that were capable of identifying different aspects of satisfaction were selected as the principal components and a component satisfaction score was assigned to each individual.

Scores for each principal component were transformed into a scale varying from 0 to 100 , where zero corresponded to minimum satisfaction and 100 to the maximum.

The study conducted t-tests to analyze differences in the mean of the satisfaction scores for each component according to the following variables: sex; schooling- incomplete fundamental and complete fundamental or higher; age group (years) - 18-39 and $40+$; feeling of discrimination for any reason - yes or no; and form of payment - SUS or non-SUS.

In the last stage, multiple regression analyses were performed separately for outpatient and impatient cares. For the principal component, the dependent variable was the satisfaction score and the independent dummy variables were: female sex, incomplete fundamental school, age 8-39 years old, discrimination experience (yes), and form of payment (SUS user).

The SUDAAN software was used in the statistical analysis, taking into consideration the sampling design and the sample expansion factor, which allows extrapolating the results to Brazil as a whole.

\section{Results}

Of the 5,000 interviewees, 1,544 (31.0\%) reported inpatient care in the five years prior to the survey. Of these, $71.0 \%$ were treated by the SUS, $22.5 \%$ paid through private health insurance, and $6.5 \%$ paid out of pocket, without reimbursement. Among the remaining participants, $2,388(69.0 \%)$ had received outpatient care at least once in the year prior to the interview. Of these, $19.0 \%$ paid out of pocket (without reimbursement), $21.0 \%$ paid through health insurance plans, and $60.0 \%$ used the SUS.

According to the evaluation of outpatient care (Table 1), "waiting time for care" showed the lowest degree of users' satisfaction among all the aspects analyzed. Meanwhile, the aspects related to intimacy, secrecy of personal information, and health professionals' skills received the highest satisfaction scores.

Also in Table 1, the percentage of users who gave "good" or "very good" ratings was lower among users of the SUS for all aspects studied, both for outpatient and inpatient care.

Among all the aspects of inpatient care (Table 1), the lowest percentage of satisfaction was attributed to "freedom to choose the physician", while aspects related to availability of medicines, adequate equipment, and respect for intimacy showed the highest users' satisfaction.

A significant proportion of outpatient care users experienced discrimination for the following reasons: $9.0 \%$ reported feeling they had been treated worse than others because of lack of money and $8.0 \%$ because of their social class (Table 2). Among users of the SUS, these figures were $11.0 \%$ and $10.0 \%$. Of all users, $1.2 \%$ reported they had been treated worse because of their skin color.

Interviewees who had been hospitalized in the previous five years reported higher discrimination rates than outpatient users, emphasizing "lack of money" and "social class" as the principal factors. Users of inpatient care in the SUS reported higher discrimination rates (Table 2).

Table 3 shows the selected factors in the principal components analysis as well as the correlations between each original variable and the selected components ("factor loadings"). Variables with factor loadings greater than 0.5 (absolute values) are shown in bold type.

For both outpatient and inpatient treatment, the variables evaluating respectful treatment, respect for intimacy, clarity of explanations, time to ask questions, information on treatment alternatives, participation in treatment decision-making, privacy with health professionals, and secrecy of personal information have high factor loadings in component 1 , which was named the "health professional factor".

Variables such as traveling time to the health care provider, waiting time, cleanliness and available space of facilities, for both outpatient 
Percentage of satisfaction according to type of care, form of payment, and aspects

related to health care user's evaluation, Brazil, 2003.

\begin{tabular}{|c|c|c|c|}
\hline & \multicolumn{2}{|c|}{ Form of payment } & \multirow[t]{2}{*}{ Total } \\
\hline & Non-SUS & SUS* & \\
\hline \multicolumn{4}{|l|}{ Outpatient care } \\
\hline Number of individuals interviewed & 961 & 1,427 & 2,388 \\
\hline \multicolumn{4}{|l|}{ Aspect } \\
\hline Traveling time to the health care provider & 78.2 & 68.8 & 72.6 \\
\hline Waiting time & 73.4 & 45.4 & 56.7 \\
\hline Being greeted and talked to respectfully & 96.6 & 86.0 & 90.2 \\
\hline Respect for intimacy during physical examination & 97.1 & 93.9 & 95.2 \\
\hline Clarity of explanations & 93.5 & 80.1 & 85.5 \\
\hline Time for questions & 90.2 & 65.9 & 75.7 \\
\hline Possibility of obtaining information on other types of treatment & 85.8 & 60.1 & 70.4 \\
\hline Participation in treatment decision-making & 85.2 & 59.8 & 70.0 \\
\hline Privacy with health professionals & 94.3 & 83.3 & 87.7 \\
\hline Secrecy of personal information & 96.7 & 89.1 & 92.2 \\
\hline Freedom to choose physician & 87.7 & 49.0 & 64.6 \\
\hline Cleanliness inside the facility & 97.6 & 79.2 & 86.6 \\
\hline Available space in waiting and examining rooms & 88.0 & 63.9 & 73.6 \\
\hline Satisfactory physician skills & 96.7 & 90.3 & 92.9 \\
\hline Adequate equipment & 96.6 & 87.7 & 91.3 \\
\hline Adequate availability of medicines & 88.2 & 75.9 & 80.8 \\
\hline \multicolumn{4}{|l|}{ Inpatient care } \\
\hline Number of individuals interviewed & 447 & 1,096 & 1,544 \\
\hline \multicolumn{4}{|l|}{ Aspect } \\
\hline Traveling time to the health care provider & 79.3 & 60.7 & 66.1 \\
\hline Waiting time & 83.3 & 67.9 & 72.4 \\
\hline Being greeted and talked to respectfully & 93.1 & 85.8 & 87.9 \\
\hline Respect for intimacy during physical examination & 96.5 & 90.3 & 92.1 \\
\hline Clarity of explanations & 89.6 & 78.3 & 81.6 \\
\hline Time questions & 86.5 & 63.0 & 69.8 \\
\hline Possibility of obtaining information on other types of treatment & 83.9 & 58.3 & 65.7 \\
\hline Participation in treatment decision-making & 82.8 & 59.1 & 65.9 \\
\hline Privacy with health professionals & 89.8 & 68.0 & 74.3 \\
\hline Secrecy of personal information & 94.9 & 81.5 & 85.5 \\
\hline Freedom to choose physician & 82.9 & 47.3 & 57.5 \\
\hline Cleanliness inside the facility & 91.2 & 78.1 & 81.9 \\
\hline Available space in waiting and examining rooms & 90.7 & 71.6 & 77.1 \\
\hline Possibility of receiving visitors & 87.1 & 70.0 & 75.0 \\
\hline Contact with outside world & 81.5 & 59.2 & 65.7 \\
\hline Satisfactory physician skills & 94.5 & 90.0 & 91.3 \\
\hline Adequate equipment & 97.0 & 90.4 & 92.3 \\
\hline Adequate availability of medicines & 97.8 & 90.8 & 92.9 \\
\hline
\end{tabular}

SUS $=$ Unified National Health System. 
Percentage of individuals who experienced some type of discrimination, according to type of care and form of payment. Brasil, 2003.

\begin{tabular}{|c|c|c|c|}
\hline & \multicolumn{2}{|c|}{ Form of payment } & \multirow[t]{2}{*}{ Tota } \\
\hline & Non-SUS & SUS & \\
\hline \multicolumn{4}{|l|}{ Outpatient care } \\
\hline \multicolumn{4}{|c|}{ Reason for discrimination } \\
\hline Sex & 1.4 & 1.4 & 1.4 \\
\hline Age & 1.5 & 2.0 & 1.8 \\
\hline Lack of money & 5.2 & 11.1 & 8.7 \\
\hline Social class & 5.2 & 9.5 & 7.8 \\
\hline Skin color & 1.0 & 1.4 & 1.2 \\
\hline Type of illness & 1.3 & 2.0 & 1.7 \\
\hline Nationality & 0.0 & 0.3 & 0.2 \\
\hline \multicolumn{4}{|l|}{ Inpatient care } \\
\hline \multicolumn{4}{|c|}{ Reason for discrimination } \\
\hline Sex & 3.1 & 2.3 & 2.5 \\
\hline Age & 2.1 & 3.7 & 3.2 \\
\hline Lack of money & 8.0 & 14.9 & 12.9 \\
\hline Social class & 7.2 & 13.1 & 11.4 \\
\hline Skin color & 1.7 & 1.4 & 1.5 \\
\hline Type of illness & 2.4 & 2.7 & 2.6 \\
\hline Nationality & 0.0 & 0.4 & 0.3 \\
\hline
\end{tabular}

Note: the percentages were calculated for the SUS and non-SUS groups out of the total number of individuals who received outpatient or inpatient care.

and inpatient cares were the ones with factor loadings greater than 0.5 in component 2 . Since these variables relate to health service access and service attributes, component 2 was named the "health services factor".

The variables related to health professionals' skills and equipment and availability of medicines in the care have high factor loadings in the third component, for both outpatient and inpatient care. Expressing how users rated the possibility of solving their health problem, this factor was called the "health problem solution factor".

These three components explained $58.0 \%$ of total variation for both outpatient and inpatient care.

In table 4 , the differences in mean satisfaction scores are analyzed. For outpatient care, the second factor (related to health service attributes) stood out with the lowest mean user satisfaction score (55), while the other two factors had mean satisfaction scores close to 71 . For inpatient care, the health problem solution factor had the highest mean satisfaction score (76), far from the mean scores given to the factors related to health professionals (63) and to health service attributes (57).
For both outpatient and inpatient care, the mean satisfaction scores showed statistical significant differences according to type of payment for the first two components, related respectively to treatment from health professionals and health services conditions. Individuals who used the SUS gave much lower ratings, with differences of greater than eight percentage points in mean satisfaction. However, for the problem solution component the differences in mean satisfaction were much smaller and were not significantly different for inpatient care.

Another aspect that consistently made a negative contribution to the degree of satisfaction was the experience of discrimination during care. For all three principal components, individuals who felt they had been treated worse than other users in outpatient and inpatient care invariably showed lower mean satisfaction score (Table 4).

The results of the multi-variate analysis of the joint influence of sex, age group, schooling, form of payment, and discrimination experience on the degree of satisfaction are presented in Table 5. Only form of payment and discrimination were consistently associated with 
Principal component analysis results by type of care: factors loading matrix. Brazil, 2003.

\begin{tabular}{|c|c|c|c|}
\hline & \multicolumn{3}{|c|}{ Components } \\
\hline & 1 & 2 & 3 \\
\hline \multicolumn{4}{|l|}{ Outpatient care } \\
\hline \multicolumn{4}{|l|}{ Aspect } \\
\hline Satisfactory physician skills & 0.295 & -0.064 & 0.687 \\
\hline Adequate equipment & 0.091 & 0.161 & 0.753 \\
\hline Adequate availability of medicines & 0.057 & 0.151 & 0.677 \\
\hline Traveling time to the health care provider & 0.148 & 0.581 & 0.018 \\
\hline Waiting time & 0.213 & 0.685 & 0.192 \\
\hline Being greeted and talked to respectfully & 0.698 & 0.219 & 0.225 \\
\hline Respect for intimacy during physical examination & 0.680 & 0.219 & 0.025 \\
\hline Clarity of explanations & 0.778 & 0.172 & 0.300 \\
\hline Time for questions & 0.755 & 0.243 & 0.251 \\
\hline Possibility of obtaining information on other types of treatment & 0.713 & 0.307 & 0.228 \\
\hline Participation in treatment decision-making & 0.684 & 0.264 & 0.268 \\
\hline Privacy with health professionals & 0.744 & 0.233 & 0.017 \\
\hline Secrecy of personal information & 0.728 & 0.251 & -0.059 \\
\hline Freedom to choose physician & 0.507 & 0.464 & 0.239 \\
\hline Cleanliness inside the facility & 0.395 & 0.659 & 0.052 \\
\hline Available space in waiting and examining rooms & 0.286 & 0.709 & 0.099 \\
\hline Variance (\%) & 42.6 & 8.6 & 6.6 \\
\hline \multicolumn{4}{|l|}{ Inpatient care } \\
\hline \multicolumn{4}{|l|}{ Aspect (evaluation) } \\
\hline Satisfactory physician skills & 0.230 & -0.020 & 0.723 \\
\hline Adequate equipment & 0.109 & 0.166 & 0.755 \\
\hline Adequate availability of medicines & 0.142 & 0.102 & 0.626 \\
\hline Traveling time to the health care provider & 0.300 & 0.427 & -0.077 \\
\hline Waiting time & 0.431 & 0.391 & 0.155 \\
\hline Being greeted and talked to respectfully & 0.603 & 0.259 & 0.364 \\
\hline Respect for intimacy during physical examination & 0.587 & 0.243 & 0.281 \\
\hline Clarity of explanations & 0.765 & 0.156 & 0.278 \\
\hline Time for questions & 0.833 & 0.240 & 0.182 \\
\hline Possibility of obtaining information on other types of treatment & 0.817 & 0.249 & 0.143 \\
\hline Participation in treatment decision-making & 0.753 & 0.241 & 0.062 \\
\hline Privacy with health professionals & 0.709 & 0.338 & 0.144 \\
\hline Secrecy of personal information & 0.611 & 0.326 & 0.148 \\
\hline Freedom to choose physician & 0.625 & 0.403 & 0.099 \\
\hline Cleanliness inside the facility & 0.249 & 0.610 & 0.333 \\
\hline Available space in waiting and examining rooms & 0.267 & 0.732 & 0.251 \\
\hline Possibility of receiving visitors & 0.222 & 0.761 & 0.090 \\
\hline Ease of staying in contact with outside world & 0.289 & 0.744 & 0.006 \\
\hline Variance (\%) & 43.2 & 7.8 & 6.5 \\
\hline
\end{tabular}


Means and standard errors of principal component satisfaction scores by type of care according to sociodemographic variables, form of payment, and discrimination experience. Brazil, 2003.

\begin{tabular}{|c|c|c|c|}
\hline & $\begin{array}{l}\text { Health } \\
\text { professional }\end{array}$ & $\begin{array}{c}\text { Components } \\
\text { Health service } \\
\text { attributes }\end{array}$ & $\begin{array}{c}\text { Health problem } \\
\text { solution }\end{array}$ \\
\hline \multicolumn{4}{|l|}{ Outpatient care } \\
\hline \multicolumn{4}{|l|}{ Sex } \\
\hline Male & $69.5 \pm 0.55$ & $55.5 \pm 0.57$ & $71.4 \pm 0.50$ \\
\hline Female & $71.5 \pm 0.55^{\star \star}$ & $53.8 \pm 0.54^{\star \star}$ & $71.4 \pm 0.58$ \\
\hline \multicolumn{4}{|l|}{ Schooling } \\
\hline Incomplete fundamental & $68.3 \pm 0.49$ & $53.7 \pm 0.55$ & $71.9 \pm 0.55$ \\
\hline Complete fundamental or greater & $73.1 \pm 0.57^{\star \star}$ & $55.5 \pm 0.52^{\star \star}$ & $70.9 \pm 0.53$ \\
\hline \multicolumn{4}{|l|}{ Age group (years) } \\
\hline $18-39$ & $70.5 \pm 0.53$ & $53.9 \pm 0.57$ & $70.3 \pm 0.53$ \\
\hline $40+$ & $70.8 \pm 0.53$ & $55.3 \pm 0.51^{\star}$ & $72.6 \pm 0.52^{\star \star}$ \\
\hline \multicolumn{4}{|l|}{ Discrimination } \\
\hline Yes & $65.4 \pm 1.22$ & $48.6 \pm 1.37$ & $65.7 \pm 1.49$ \\
\hline No & $71.2 \pm 0.43^{* *}$ & $55.3 \pm 0.40^{* *}$ & $72.1 \pm 0.40^{* *}$ \\
\hline \multicolumn{4}{|l|}{ Form of payment } \\
\hline SUS & $67.1 \pm 0.52$ & $51.2 \pm 0.56$ & $70.4 \pm 0.54$ \\
\hline Non-SUS & $75.9 \pm 0.50^{\star \star}$ & $59.5 \pm 0.42^{\star \star}$ & $72.9 \pm 0.45^{\star \star}$ \\
\hline Total & $70.6 \pm 0.43$ & $54.6 \pm 0.42$ & $71.4 \pm 0.39$ \\
\hline \multicolumn{4}{|l|}{ Inpatient care } \\
\hline \multicolumn{4}{|l|}{ Sex } \\
\hline Male & $63.6 \pm 0.82$ & $56.9 \pm 0.67$ & $76.6 \pm 0.63$ \\
\hline Female & $61.9 \pm 0.66$ & $56.8 \pm 0.59$ & $76.0 \pm 0.62$ \\
\hline \multicolumn{4}{|l|}{ Schooling } \\
\hline Incomplete fundamental & $61.2 \pm 0.70$ & $55.8 \pm 0.54$ & $76.9 \pm 0.59$ \\
\hline Complete fundamental or greater & $64.18 \pm 0.77^{\star \star}$ & $58.1 \pm 0.73^{\star *}$ & $75.4 \pm 0.69$ \\
\hline \multicolumn{4}{|l|}{ Age group (years) } \\
\hline $18-39$ & $60.9 \pm 0.71$ & $56.4 \pm 0.62$ & $76.0 \pm 0.60$ \\
\hline $40+$ & $64.5 \pm 0.73^{\star \star}$ & $57.3 \pm 0.65$ & $75.6 \pm 0.67$ \\
\hline \multicolumn{4}{|l|}{ Discrimination } \\
\hline Yes & $55.9 \pm 1.26$ & $50.0 \pm 1.13$ & $72.0 \pm 1.71$ \\
\hline No & $63.7 \pm 0.60 * *$ & $58.1 \pm 0.48^{\star \star}$ & $77.0 \pm 0.45^{\star \star}$ \\
\hline \multicolumn{4}{|l|}{ Form of payment } \\
\hline SUS & $59.8 \pm 0.62$ & $54.2 \pm 0.55$ & $75.9 \pm 0.64$ \\
\hline Non-SUS & $68.7 \pm 0.71^{\star \star}$ & $62.8 \pm 0.65^{\star \star}$ & $76.9 \pm 0.53$ \\
\hline Total & $62.5 \pm 0.58$ & $56.8 \pm 0.48$ & $76.2 \pm 0.48$ \\
\hline
\end{tabular}

* Significant at $5.0 \%$;

** Significant at $1.0 \%$. 
degree of satisfaction. Although the coefficients for the other variables were significant in some components, the effects were not systematic and sometimes acted in opposite directions.

\section{Discussion}

This study involves an evaluation of health care from the health services user's perspective. According to some authors 8 , the "quality" dimension should consider who defines it, so that a "high-quality" service is inconceivable if the users are dissatisfied.

Analysis of data from the Brazilian WHS pointed to three major components: the first was strongly correlated with variables expressing degree of satisfaction with care received from health professionals; the second reflects satisfaction with health service access and service attributes; and the third relates mainly to the issue of health problem solution. The lowest degree of satisfaction was obtained for the second of the three components, both in outpatient and inpatient care.

Thus, from the perspective of health services users in Brazil, satisfaction with care is related to quality of treatment provided by health professionals, the care received, and the solution to the health problem, but above all to access to the health services and their installations.
According to Donabedian $18,30.0$ to $40.0 \%$ of health care users' satisfaction is explained by the physician's diagnostic and therapeutic skill and 40.0 to $50.0 \%$ by the physician-patient relationship. In Brazil, the most important factor for dissatisfaction is the lack of free choice of the physician, an indicator both of the physician-patient relationship and difficulties in access to health services.

The results of the current analysis corroborate findings from other studies in Brazil, indicating deterioration in health services quality. According to Assis et al. 19, the main complaints relating to medical care were: delay; several visits to the health service to obtain treatment; and lack of guarantee in obtaining exams or even treatment continuity.

According to a qualitative study in a university hospital in Rio de Janeiro, the most frequent complaints referred to the care received from the health professional, for example lack of attention, disinterest, lack of human warmth, lack of punctuality, and limited time devoted to the consultation. However, user ratings were very different for pediatricians, who received high satisfaction scores due to the communications style adopted by this specialty and the extensive information provided to mothers 9 .

In a study in the State of Ceará, Caprara \& Rodrigues 1 observed that approximately $40.0 \%$ of physicians failed to provide patients with a

Multiple regression results using principal components satisfaction scores as dependent variables by type of care. Brazil, 2003.

\begin{tabular}{|c|c|c|c|c|c|c|}
\hline & \multicolumn{2}{|c|}{ Health professional } & \multicolumn{2}{|c|}{$\begin{array}{l}\text { Health service } \\
\text { attributes }\end{array}$} & \multicolumn{2}{|c|}{$\begin{array}{l}\text { Health problem } \\
\text { solution }\end{array}$} \\
\hline & $\beta$ & $p$ value & $\beta$ & $p$ value & $\beta$ & $p$ value \\
\hline \multicolumn{7}{|l|}{ Outpatient care } \\
\hline \multicolumn{7}{|l|}{ Variables } \\
\hline Female sex & 2.37 & 0.0005 & -1.47 & 0.0244 & -0.02 & 0.9769 \\
\hline Incomplete fundamental school & -2.28 & 0.0008 & 0.52 & 0.4526 & 1.47 & 0.0681 \\
\hline Age 18-39 years old & -0.96 & 0.1065 & -1.41 & 0.0416 & -1.82 & 0.0117 \\
\hline Discrimination experience (yes) & -4.61 & 0.0001 & -5.60 & 0.0000 & -6.14 & 0.0001 \\
\hline SUS & -7.93 & 0.0000 & -8.25 & 0.0000 & -2.74 & 0.0001 \\
\hline \multicolumn{7}{|l|}{ Inpatient care } \\
\hline \multicolumn{7}{|l|}{ Variables } \\
\hline Female sex & -0.80 & 0.3521 & 0.23 & 0.7653 & -0.44 & 0.6016 \\
\hline Incomplete fundamental school & -1.66 & 0.0824 & -0.11 & 0.8949 & 1.85 & 0.0581 \\
\hline Age 18-39 years old & -3.14 & 0.0005 & -0.13 & 0.8734 & 0.06 & 0.9402 \\
\hline Discrimination experience (yes) & -6.84 & 0.0000 & -7.15 & 0.0000 & -4.86 & 0.0053 \\
\hline SUS & -7.50 & 0.0000 & -8.05 & 0.0000 & -1.22 & 0.1890 \\
\hline
\end{tabular}


clear and comprehensive explanation of their problem; in $58.0 \%$ of consultations, the physician failed to ascertain the patient's level of understanding concerning the diagnosis; and in $53.0 \%$ of cases the physicians also failed to verify the patient's understanding of the treatment instructions. Users' dissatisfaction with these aspects, also observed in the Brazilian WHS brings back a longstanding discourse according to which doctors not only fail to recognize patients as "subjects" capable of taking responsibility for their own care, but also neglect to encourage patients' autonomy and participation in the treatment adherence process, preventive practices, and health promotion 1 .

Furthermore, the Brazilian WHS showed that the main problems identified by health services clientele were the same in the two groups of users, namely those that paid and those that did not pay for the services provided. However, the degree of satisfaction with publicly provided care was invariably lower. Although it is plausible that users with higher socioeconomic status also have higher expectations and are thus more rigorous in rating the services provided, thereby generating greater levels of dissatisfaction, the results of the WHS do not confirm this hypothesis. Possible explanations may lie in the better quality of private services or that expectations are already high among the population, both for users and nonusers of SUS.
Brazil experiences selective and exclusionary access, which are related to inequalities in health care access and distribution of benefits, according to the user's purchasing power, leading to deterioration in the quality of care provided by public services.

Another serious problem identified by analysis of the WHS data was the high percentage of individuals who felt discrimination, regardless of the form of payment for care. Discrimination was also one of the principal reasons for dissatisfaction in all aspects of provided health care. The principal sources of discrimination identified by respondents were lack of money and social class. It is important to note that the percentages of individuals who felt they had been treated worse than other on grounds of social exclusion were consistently higher among users of the National Health System, a practice that runs counter to the guiding principles of the Brazilian health system.

In sum, the WHS data raised several issues at the national level that had already been identified in local studies, besides pointing to other problems detected by users, which could back the reorientation of health care organization in Brazil. However, while the instrument proposed by the WHO brought the benefits of innovation, in the other hand, although it was adapted to the Brazilian case, it failed to approach fundamental aspects of health care in the country, especially in relation to the identification of criteria that characterize "satisfaction" in the different population groups.

\section{Resumo}

A avaliação da satisfação com o sistema de saúde sob a ótica do usuário recoloca antigos questionamentos quanto à qualidade dos serviços oferecidos à população brasileira. Este trabalho analisa os resultados sobre satisfação com a assistência de saúde prestada (ambulatorial e internação) da Pesquisa Mundial de Saúde, realizada no Brasil no ano de 2003. Com o objetivo de explicar a satisfação com o atendimento em seus aspectos por meio de um pequeno número de fatores, foi utilizada a técnica de análise fatorial por componentes principais (ACP). Modelos de regressão múltipla permitiram identificar associações dos escores de satisfação com diferentes variáveis sócio-demográficas. O tempo de espera foi o item que demons- trou menor grau de satisfação, no caso de atendimento ambulatorial, e a liberdade de escolha do profissional de saúde, no caso de internação. Na ACP foram extraídos três componentes, que se relacionaram à satisfação com os profissionais, serviços e resolução do problema de saúde. A regressão múltipla revelou que ter sofrido algum tipo de discriminação (por sexo, idade, pobreza, classe social, raça ou tipo de doença) $e$ ser usuário exclusivo do SUS implica o menor grau de satisfação dos usuários com o atendimento recebido.

Satisfação dos Consumidores; Discriminação no Setor Saúde; Sistema de Saúde 


\section{Contributors}

G. C. Gouveia and W. V. Souza participated in the data analysis and drafting of the article. C. F. Luna and P. B. Souza-Júnior participated in the statistical analysis. C. L. Szwarcwald participated in the data analysis and revision of the article.

\section{Referências}

1. Caprara A, Rodrigues J. A relação assimétrica médico-paciente: repensando o vínculo terapêutico. Ciênc Saúde Coletiva 2004; 9:139-46.

2. Comissão de Saúde, Câmara dos Deputados. Proposta política para um programa de saúde. Saúde Debate 1984; 33-6.

3. Costa NR. Políticas públicas, direitos e interesses: reforma sanitária e organização sindical no Brasil. Saúde Debate 1994; 45:23-9.

4. Luz TM. Notas sobre as políticas de saúde no Brasil de "transição democrática" - anos 80. Saúde Debate 1991; 32:27-32.

5. Sampaio BP. O SUS, a Constituição e a lei: a posição do Conselho Nacional de Secretários de Saúde. Saúde Debate 1993; 40:9-12.

6. Noronha JC, Levcovitz E. AIS-SUDS-SUS: os caminhos do direito à saúde. In: Guimarães R, Tavares $\mathrm{R}$, organizadores. Saúde e sociedade no Brasil: anos 80. Rio de Janeiro: ABRASCO; 1994. p. 73-111.

7. Nitão SRV. Regulamentação do Sistema Único de Saúde: a próxima batalha. Saúde Debate 1989; 24:24-5.

8. Akerman M, Nadanovsky P. Avaliação dos serviços de saúde: avaliar o quê? Cad Saúde Pública 1992; 8:361-5.

9. Lemme AC, Noronha G, Resende JB. A satisfação do usuário em Hospital Universitário. Rev Saúde Pública 1991; 25:41-6.

10. Ramos DD, Lima MADS. Acesso e acolhimento aos usuários em uma unidade de saúde de Porto Alegre, Rio Grande do Sul, Brasil. Cad Saúde Pública $2003 ;$ 19:27-34.

\section{Acknowledgments}

This study received financial support from the Conselho Nacional de Desenvolvimento Científico e Tecnológico (CNPq) and the Departamento de Ciência e Tecnologia, Ministério da Saúde (DECIT, MS).

11. Duchiade MP. População brasileira: um retrato em movimento. In: Minayo MC, organizador. Os muitos Brasis: saúde e população na década de 80. Rio de Janeiro: ABRASCO; 1995. p. 14-56.

12. Paim JS. Abordagens teórico-conceituais em estudos de condições de vida e saúde: notas para reflexão e ação. In: Barata $\mathrm{RB}$, organizador. Condições de vida e situação em saúde. Rio de Janeiro: ABRASCO; 1997. p. 7-30.

13. Donabedian A. Evaluación de la calidad de la atención médica. Investigaciones sobre servicios de salud: una antología. Washington DC: Organización Panamericana de la Salud; 1992. (Publicación Científica 534).

14. Vuori H. A qualidade da saúde. Divulg Saúde Debate $1991 ; 3: 17-25$.

15. Instituto Brasileiro de Geografia e Estatística. Acesso e utilização de serviços de saúde: 2003. Rio de Janeiro: Instituto Brasileiro de Geografia e Estatística; 2005.

16. Ustun TB, Chatterji S, Villanueva M, Celik LBC, Sadana R, Valentine N, et al. Multi-country Survey Study on Health and Responsiveness 20002001. Geneva: World Health Organization; 2001. (GPE Discussion Paper 37).

17. Green P. Analyzing multivariate data. Hinsdale: The Dryden Press; 1978.

18. Donabedian A. La qualita dell'assistenza sanitaria. Roma: NIS; 1990.

19. Assis MMA, Villa TCS, Nascimento MAA. Acesso aos serviços de saúde: uma possibilidade a ser construída na prática. Ciênc Saúde Coletiva 2003; 8:815-23.

Submitted on 04/May/2005

Final version resubmitted on 18/Oct/2005 Approved on 19/Oct/2005 